\title{
Yield and biochemical composition of a marine cyanobacterium (Nodularia sp.) in outdoor culture
}

\author{
Benjamin Pushparaj, Elio Pelosi, Pietro Carlozzi, Giuseppe Torzillo
}

Centro di Studio dei Microrganismi Autotrofi, CNR, P. le delle Cascine, I-27-50144 Firenze, Italy

\begin{abstract}
The results are reported of an investigation into biomass output of $\mathrm{N}_{2}$-fixing marine cyanobacterium Nodularia sp. grown outdoors in open ponds (OPs) and in tubular photobioreactors (TPRs). The productivity in TPR was $13.2 \mathrm{~g}(\mathrm{dw}) \mathrm{m}^{-2} \mathrm{~d}^{-1}$, while in OP it was $11.0 \mathrm{~g}(\mathrm{dw}) \mathrm{m}^{-2} \mathrm{~d}^{-1}$. The higher productivity obtained in TPR compared to OP was probably due to a better temperature control in the system. Both true protein content and amino acid composition were very similar to that reported for Spirulina. The photoinhibitory effects of high light intensity on the photosynthetic activity of Nodularia was considerably reduced by using a black net for culture shading, which improved photosynthetic activity of the cyanobacterium.
\end{abstract}

KEY WORDS: Marine cyanobacterium - Nodularia sp. Outdoor culture - Photobioreactors

\section{INTRODUCTION}

Photosynthetic microorganisms are highly efficient in primary production given their simple structural organization and their capacity to efficiently utilize solar energy and available nutrients. In this group, the marine $\mathrm{N}_{2}$-fixing cyanobacteria appear to be particularly attractive for biomass production as they are able to fix atmospheric nitrogen using sunlight. This opens important prospects for the exploitation of coastal areas that are unsuitable for conventional aquaculture. Recently, the interest in the mass culture of these microorganisms has been focused mainly on their use as a source of food protein for aquaculture organisms (Mitsui et al. 1981) and for the production of fine chemicals (Benemann \& Weisemann 1984). However, it was observed that cyanobacteria in an outdoor culture were very sensitive to high light intensity, often resulting in low productivity. Vonshak \& Richmond (1988) demonstrated that shading the culture could reduce the adverse effect of high irradiation. Further mass culture of these phototrophs in seawater presented many technical limitations such as an adequate $\mathrm{pH}$ maintenance in the culture medium to avoid precipitation of phosphate and other nutrients. These drawbacks have been successfully overcome in further studies conducted in recent years (e.g. Materassi et al. 1984,
Tredici et al. 1986). In this paper the possibility of growing Nodularia sp. outdoors in open ponds and in tubular photobioreactors was examined to compare the yield obtained in both systems. The effect of shading on $\mathrm{O}_{2}$ evolution and biomass output is also reported.

\section{MATERIALS AND METHODS}

The Nodularia strain (S.E. 1) isolated from S. Eufemia gulf seawater (southern Italy), was grown both in the laboratory and outdoors in an artificial seawater medium (ASW) containing $\left(\mathrm{g}^{-1}\right)$ : 33.0 sea salts (Tropic marin neu), $0.03 \mathrm{~K}_{2} \mathrm{HPO}_{4}, 0.005 \mathrm{Fe}$ (as Fe-EDTA) and Arnon solution A5 $\left(1 \mathrm{ml} \mathrm{l}^{-1}\right)$. The $\mathrm{pH}$ of the sea water medium was maintained at 7.5 by the addition of pure $\mathrm{CO}_{2}$ in the culture through a $\mathrm{pH}$ stat system (Claind s.r.l., Milan, Italy). The laboratory cultures were maintained at an optimum temperature $\left(28^{\circ} \mathrm{C}\right)$ and illuminated under an incidental light intensity of $50 \mu \mathrm{E} \mathrm{m}$ $\mathrm{s}^{-1}$.

Outdoor culture. Growth experiments with Nodularia sp. were performed in a semi-continuous regimen from June to August in 2 culture systems: open raceway ponds (OPs) and closed tubular photobioreactors (TPRs). In OP ( $4 \mathrm{~m}^{2}$ surface area), the culture level was 
Table 1. Analysis of variance for yield in 2 culture systems in different months

\begin{tabular}{|lrrrrr|}
\hline Factors & $\begin{array}{c}\text { Sum of } \\
\text { squares }\end{array}$ & df & $\begin{array}{c}\text { Mean } \\
\text { square }\end{array}$ & F-ratio & $\begin{array}{c}\text { Sig. } \\
\text { level }\end{array}$ \\
\hline Main effects & & & & & \\
$\quad$ Culture system & 157.80 & 1 & 157.80 & 86.31 & 0.0000 \\
$\quad$ Months & 169.50 & 2 & 84.75 & 46.36 & 0.0000 \\
Residual & 210.26 & 115 & 1.83 & & \\
Total & 533.87 & 118 & & & \\
\hline
\end{tabular}

Table 2. Analysis of variance for growth yield $\left(Y_{g}\right)$ of shaded and unshaded cultures at different hours of the day

\begin{tabular}{|lrrrrr|}
\hline Factors & $\begin{array}{c}\text { Sum of } \\
\text { squares }\end{array}$ & df & $\begin{array}{c}\text { Mean } \\
\text { square }\end{array}$ & F-ratio & $\begin{array}{c}\text { Sig. } \\
\text { level }\end{array}$ \\
\hline $\begin{array}{l}\text { Main effects } \\
\text { Hours }\end{array}$ & 2797.92 & 6 & 466.320 & 16.153 & 0.0000 \\
$\begin{array}{l}\text { Shaded and } \\
\text { unshaded cultures }\end{array}$ & 6599.32 & 1 & 6599.324 & 228.598 & 0.0000 \\
Residual & 3810.67 & 132 & 28.868 & & \\
Total & 13207.91 & 139 & & & \\
\hline
\end{tabular}

Analytical methods. Biomass was determined in triplicate by filtering $25 \mathrm{ml}$ samples of cultures through a membrane $(8 \mu \mathrm{m})$ washed with distilled water and dried at $105^{\circ} \mathrm{C}$ to constant weight. The productivity was calculated from the dry weight increase over $24 \mathrm{~h}$. The elemental composition $(\mathrm{C}, \mathrm{H}, \mathrm{N}, \mathrm{O})$ of lyophilized biomass was determined by means of an elemental analyser (Model 1106, Carlo Erba Strumentazione, Milan). The crude protein, calculated as $N \times 6.25$, included nucleic acids and other non-proteic compounds such as chlorophyll a (Herbert et al. 1971). Carbohydrate content was determined by the phenol-sulphuric acid method using $D(+) g l u c o s e$ as standard (Dubois et al. 1956). True protein was calculated from amino acid concentration, determined with HPLC (Mod. Enzyme assay). Total solar radiation was measured with a Micros solarimeter, using a Kipp and Zonen $\mathrm{CH}$ 5/6 pyranometric sensor.

Statistics. The data on the productivity of Nodularia sp. grown in the 2 systems (open pond and tubular photobioreactor) were subjected to a multifactor analysis of variance (ANOVA), where the culture systems and months were the main factors (Table 1). $Y_{g}$ of this cyanobacterium grown in TPR under shaded and unshaded conditions was compared by means of a similar statistical analysis, where time of sampling, shaded and unshaded culture were the 2 main factors (Table 2). In both cases, the sum of squares related to the interaction was pooled with the experimental error. No data conversion was applied because the factor variances were homogeneous according to Bartlett's test. Means comparisons were performed with Tukey's test with $\mathrm{p}=0.05$

\section{RESULTS AND DISCUSSION}

\section{Biomass yield in the 2 systems}

Fig. 1 illustrates the comparative biomass yield obtained in the outdoor experiments conducted with marine cyanobacterium Nodularia sp. in OP and TPR from June to August. The average productivity $[11.0 \mathrm{~g}$ (dw) $\mathrm{m}^{-2}$ in $O P$ and $13.2 \mathrm{~g}(\mathrm{dw}) \mathrm{m}^{-2}$ in TPR), during the experimental period, was significantly higher $(+20 \%$, $p=0.01$ ) in the photobioreactor than that in the open pond. The higher productivity observed in TPR was possibly due to the better temperature conditions maintained during both night and day. Indeed, the electrode. 


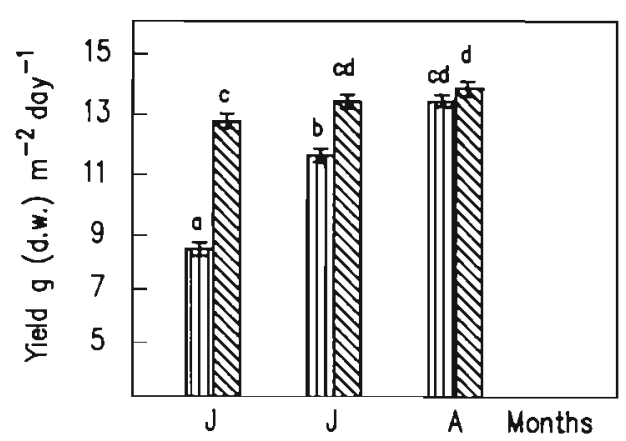

Fig. 1. Comparison of the mean yield of Nodularia sp. grown in ponds (vertical hatched columns) and photobioreactors (oblique hatched columns). Average of 20 replicates \pm confidence intervals for $p=0.05$

temperature maintained in the closed system possibly allowed a better utilization of light energy during the day compared to open pond, where the low morning temperature, far below $28^{\circ} \mathrm{C}$, probably prevented a full exploitation of morning radiation for a few hours, thus delaying the resumption of an active photosynthesis. A similar observation was made by Balloni et al. (1981) in outdoor mass culture of a green algae, by Vonshak \& Richmond (1988) and Torzillo et al. (1991) with Spirulina.

Dissolved oxygen concentration in the OP varied from $7 \mathrm{ppm}$ in the morning to $25 \mathrm{ppm}$ at the maximum light intensity period (13:00 h).

\section{Chemical composition}

In Tables $3 \& 4$, the biochemical, elemental and amino acid composition of Nodularia sp. are shown. The biochemical composition of Nodularia sp. biomass grown in the 2 systems at full sunlight showed no significant difference. Furthermore, the cultures grown in TPR under shaded and unshaded conditions did not evidence any significant difference in the biomass

Table 3. Protein and carbohydrate content of Nodularia sp. grown in open pond (OP) and tubular photobioreactor (TPR). Data, expressed as percentage of dry weight, are the average of 6 analyses, each \pm standard deviation

\begin{tabular}{|lcr|}
\hline & OP & \multicolumn{1}{c|}{ TPR } \\
\hline Crude protein & $61.5 \pm 0.39$ & $63.9 \pm 0.15$ \\
True protein & $49.3 \pm 0.13$ & $50.9 \pm 0.20$ \\
Carbohydrate & $19.0 \pm 0.23$ & $20.6 \pm 0.18$ \\
Ash & $8.3 \pm 0.19$ & $5.3 \pm 0.08$ \\
Heat of combustion & $5.5 \pm 0.058$ & $5.3 \pm 0.05$ \\
\hline
\end{tabular}

Table 4. Amino acid composition of protein from Nodularia sp. and Spirulina platensis (data from Paoletti et al. 1980) grown in TPR at full sunlight expressed as $\mathrm{mg}$ aa per $100 \mathrm{mg}$ protein. Data are the average of 3 replicate samples \pm standard deviation

\begin{tabular}{|lcr|} 
& Nodulariasp. & Spirulina platensis \\
\hline Aspartic acid & $10.8 \pm 0.26$ & $11.7 \pm 0.16$ \\
Histidine & $1.8 \pm 0.17$ & $2.0 \pm 0.06$ \\
Arginine & $6.1 \pm 0.21$ & $7.4 \pm 0.10$ \\
Serine & $2.4 \pm 0.32$ & $4.9 \pm 0.60$ \\
Glutamic acid & $13.8 \pm 0.29$ & $17.5 \pm 0.64$ \\
Proline & $5.1 \pm 0.13$ & $4.1 \pm 0.06$ \\
Glycine & $5.8 \pm 0.32$ & $6.3 \pm 0.07$ \\
Alanine & $7.0 \pm 0.22$ & $9.3 \pm 0.07$ \\
Cysteine & $0.4 \pm 0.14$ & $0.3 \pm 0.13$ \\
Valine & $6.7 \pm 0.28$ & $8.1 \pm 0.21$ \\
Methionine & $0.8 \pm 0.11$ & $2.6 \pm 0.10$ \\
- - diaminopimelic & Trace & $1.3 \pm 0.07$ \\
lsoleucine & $5.9 \pm 0.28$ & $6.7 \pm 0.21$ \\
Leucine & $8.6 \pm 0.17$ & $10.9 \pm 0.17$ \\
Tyrosine & $3.3 \pm 0.29$ & $4.8 \pm 0.16$ \\
Phenylalanine & $5.8 \pm 0.37$ & $5.7 \pm 0.00$ \\
Lysine & $4.6 \pm 0.26$ & $5.2 \pm 0.20$ \\
Threonine & $4.4 \pm 0.16$ & $5.3 \pm 0.07$ \\
Tryptophan & nd & $1.5 \pm 0.10$ \\
Ammona & $3.8 \pm 0.17$ & $0.9 \pm 0.06$ \\
& & \\
nd: not determined & & \\
\hline
\end{tabular}

compositions (results not shown). It was also interesting to note that a high true-protein content (51\%) and amino acid pattern were in the range of that reported for Spirulina (Paoletti et al. 1980), a cyanobacterium utilized as a source of protein in various feed trials. The phycocyanin and chlorophyll contents of the biomass obtained from OP was significantly higher $(\mathrm{p}=0.01)$, by $24 \%$ and $15 \%$ respectively, than that grown in TPR (1-way ANOVA, data not shown).

\section{Photosynthetic activity at different light intensities}

The photosynthetic activity of cultures grown in TPRs, exposed to 2 different light intensities, is shown in Fig. 2. The rate of oxygen evolution of Nodularia cells taken at $2 \mathrm{~h}$ intervals from the photobioreactor exposed to full sunlight $\left(850 \mathrm{~W} \mathrm{~m}^{-2}\right)$ showed a drastic decrease at about 13:00 h to $65 \%$ of that measured in the morning at the begining of the experiments. In the late afternoon $(18: 30 \mathrm{~h})$, the photosynthetic activity was back to $80 \%$ of the morning level. In contrast, in the shaded culture the specific rate of $\mathrm{O}_{2}$ evolution remained at an almost constant high level throughout the day. The corresponding biomass yield obtained in the 2 photobioreactors exposed to different light intensities showed only an $8 \%$ increase in the shaded cul- 


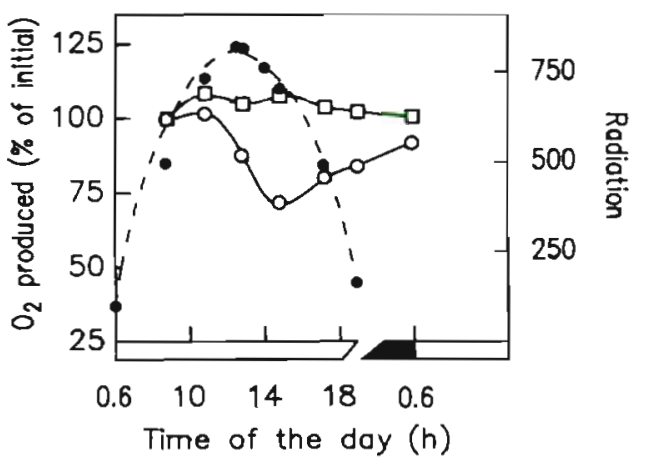

Fig. 2. Effect of shading on oxygen evolution of Nodularia sp. grown outdoors in TPR. (O) $\mathrm{O}_{2}$ without black net; (ㅁ) $\mathrm{O}_{2}$ with black net; (e) solar radiation $\left(\mathrm{W} \mathrm{m}^{-2}\right)$. Each point represents the average of 10 replicates; confidence intervals were omitted as the values were very low $\left(0.79 \%\right.$ of $\left.\mathrm{O}_{2}\right)$

ture. However, the growth yields ( $\left.Y_{\mathrm{g}}\right)$ in TPR covered with a black net was $0.665 \mathrm{~g}(\mathrm{dw}) \mathrm{MJ}^{-1}$, while in the uncovered reactor it was $0.596 \mathrm{~g}(\mathrm{dw}) \mathrm{MJ}^{-1}$, showing a very significant difference $(p=0.006)$ between them. The results indicated that the increase in growth yield $(11.6 \%)$ and the high efficient photosynthetic activity observed in the shaded culture were probably the consequence of a low photostress experienced by the cultures during high light intensity.

Acknowledgements. The authors thank A. Sacchi, D. Mannelli, and $M$. Anichini for their help and technical assistance and Dr G. Bartolini and P. Pestelli, of the Institute for the Propagation of Woody Plants, CNR, Scandicci (Italy) for statistical analysis.

\section{LITERATURE CITED}

Balloni W, Materassi R, Pelosi E, Pushparaj B, Florenzano G, Stengal E, Soeder CJ (1981) Comparison of two different devices for mass production of microalgae at Firenze (Italy) and Dortmund (Germany). Yields of Scenedesmus obliquus and Coelastrum sphaericum at Firenze. Arch Hydrobiol, Suppl 60:324

Benemann JC, Weiseman JC (1984) Chemicals from microalgae. In: Wise DL (ed) Bioconversion system. CRC Press, Boca Raton, p 59

Bocci F, Torzillo G, Vincenzini M, Materassi R (1987) Growth physiology of Spirulina platensis in tubular photobioreactor under natural light. In: Stadler $T$, Mollion J, Verdus MC, Karamanos Y, Morvan H, Christian D (eds) Algal biotechnology. Elsevier Applied Science, New York, p 219-229

Dubois M, Gilles KA, Hamilton JK, Roberts PA, Smith F (1956) Colorimetric method for determination of sugars and related substances. Analyt Chem 28:350-356

Herbert D, Phipps PJ, Strange RE (1971) Chemical analysis of microbial cells In: Norris JR, Ribbons DJ (eds) Methods in microbiology. Academic Press, London

Materassi R, Tredici MR, Balloni W (1984) Spirulina culture in seawater. Appl microbiol Biotechnol 47:384-386

Mitsui A, Murray R, Entemann B, Miyazawa K, Polk E (1981) Utilization of marine blue-green algae and macroalgae in warm mariculture. In: San Pietro A (ed) Biosaline research. Plenum Press, New York

Paoletti C, Vincenzini M, Bocci F, Materassi R (1980) Composizione biochimica generale delle biomasse di Spirulina platensis e $S$ maxima. In: Materassi $R$ (ed) Atti del convegno 'Prospettive della coltura di Spirulina in Italia' Accademia dei Georgofilip, Firenze, p 111-125

Torzillo G, Sacchi A, Materassi R, Richmond A (1991) Effect of temperature on yield and night biomass loss in Spirulina platensis grown outdoors in tubular photobioreactors. $J$ appl Phycol 3:103-109

Tredici MR, Papuzzo T, Tomaselli L (1986) Outdoor mass culture of Spirulina maxima in sea-water. Appl microbiol Biotechnol 24:47-50

Vonshak A, Richmond A (1988) Mass production of the bluegreen alga Spirulina. An overview. Biomass 15:233-247 